\title{
Use of the glycemic index in nutrition education
}

\author{
Uso do índice glicêmico na \\ educação nutricional
}

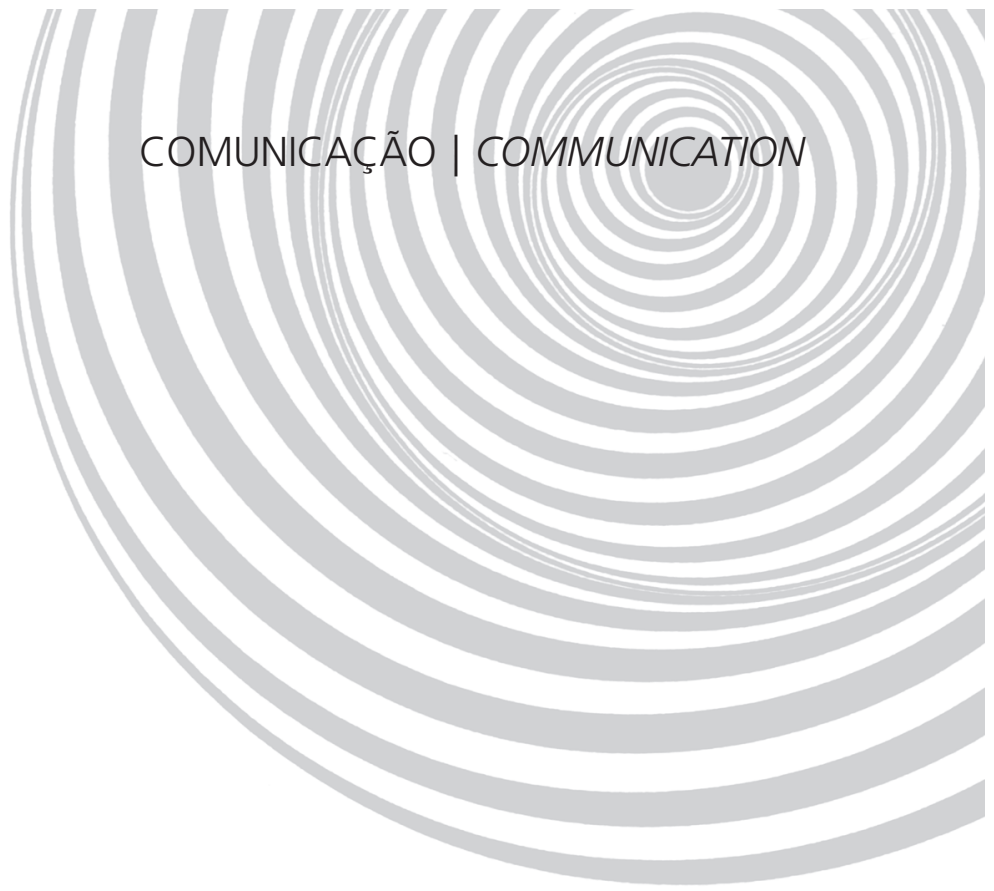

Flávia Galvão CÂNDIDO'

Elisângela Vitoriano PEREIRA'

Rita de Cássia Gonçalves ALFENAS ${ }^{1}$

\section{A B S T R A C T}

Recently, the lack of studies providing practical guidance for the use of the glycemic index has been indicated as the cause of its little use in nutrition education. The aim of this study is to give instructions on the use of the glycemic index as a tool to be used in nutrition education to estimulate the consumption of low glycemic index foods. Studies published over the past 12 years, in addition to classic studies on this topic, found in the databases MedLine, ScienceDirect, SciELO and Lilacs exploring the importance of the glycemic index and the factors that affect the glycemic index were selected for this article. The preparation of lists grouping foods according to their glycemic index should be based on information found in tables and specific web sites. This is an interesting strategy that must be very carefully conducted, considering the eating habits of the assisted people. To reduce the postprandial blood glucose response, high glycemic index foods should be consumed in association with the following foods: high protein and low fat foods, good quality oils and unprocessed foods with high fiber content. Caffeine should also be avoided. The glycemic index should be considered as an additional carbohydrate-selection tool, which should be part of a nutritionally balanced diet capable of promoting and/or maintaining body weight and health.

Indexing terms: Chronic disease. Food and nutrition education. Blood glucose. Glycemic index.

RE S U M O

Recentemente, a falta de artigos que visam fornecer orientação quanto ao uso do índice glicêmico foi apontada como causa de sua baixa utilização na educação nutricional. O objetivo do presente trabalho é oferecer suporte para o uso do índice glicêmico como ferramenta a ser adotada na educação nutricional, para estimular o consumo preferencial de alimentos que apresentem menores valores nesse indicador. Foram selecionados estudos publicados nos últimos doze anos, além de estudos clássicos referentes ao tema, indexados nos bancos de dados MedLine, ScienceDirect, SciELO e Lilacs, que exploraram a importância do índice glicêmico e os

1 Universidade Federal de Viçosa, Departamento de Nutrição e Saúde, Programa de Pós-Graduação em Ciência da Nutrição. Av. PH Rolfs, s/n., Campus Universitário, 36571-000, Viçosa, MG, Brasil. Correspondência para/Correspondence to: FG CÂNDIDO. E-mail: <flaviagcandido@hotmail.com>. 
fatores que interferem em seu valor. A elaboração de listas agrupando os alimentos segundo o índice glicêmico deve ser feita com base nas informações encontradas em tabelas e sites específicos. Essa é uma estratégia interessante que deve ser conduzida de maneira criteriosa, considerando-se os hábitos alimentares do público assistido. Para resultar em resposta glicêmica pós-prandial mais baixa, os produtos de alto índice glicêmico devem ser ingeridos em associação com alimentos ricos em proteína e pobres em gordura, com óleos de boa qualidade, com alimentos menos processados por ricos em fibras, evitando-se os com alto teor em cafeína. $O$ índice glicêmico deve ser considerado uma ferramenta adicional para a escolha de alimentos fonte de carboidratos, os quais devem ser incluídos em uma dieta nutricionalmente equilibrada, capaz de promover elou manter tanto o peso corporal adequado quanto a saúde.

Termos de indexação: Doenças crônicas. Educação alimentar e nutricional. Glicemia. Índice glicêmico.

\section{INTRODUCTION}

The Glycemic Index (GI) was developed at the beginning of the 1980s by Jenkins et al. ${ }^{1}$, and is used to classify the quality of dietary Carbohydrate (CHO). The $\mathrm{Gl}$ of a food is determined by comparing the its impact on the postprandial blood glucose level to this same type of response obtained from a reference food ${ }^{2}$.

In the laboratory, Gl is determined by the relationship between the incremental area under the Blood Glucose Response Curve (IAUC) of the test food/meal and the IAUC of the reference food (white bread or glucose). Blood glucose response is assessed after the ingestion of a portion of the test or reference food, normally containing 25 or $50 \mathrm{~g}$ of available carbohydrate. The available carbohydrate content can be determined by subtracting the total fiber content from the total carbohydrate content of the food or meal. The equations used for calculating the $\mathrm{Gl}$ are3:

Available carbohydrate $(\mathrm{g})=$ Carbohydrate Total $(\mathrm{g})$ - Dietary fibers $(\mathrm{g})$

$$
G I=\frac{\text { test food IAUC } \times 100}{\text { reference food IAUC }}
$$

The glycemic index of meals can also be estimated by equations that consider the total available carbohydrate of the meal, the percentage contribution of the available carbohydrate content of each food of the meal and the Gl of each food, as described below ${ }^{3,4}$ :

$\mathrm{Gl}=\sum$ relative $\mathrm{Gl}$ of each food of the meal

Relative Gl of the food

$$
=\frac{\text { available } \mathrm{CHO}(\mathrm{g}) \times \mathrm{Gl} \text { of the food }}{\text { available } \mathrm{CHO} \text { of the meal }(\mathrm{g})}
$$

The glycemic index has received and maintained the interest of academics and dieticians worldwide since its development ${ }^{5}$. Many internationally relevant agencies, like the Food and Agriculture Organization (FAO) ${ }^{3}$, European Association for the Study of Diabetes ${ }^{6}$ and National Health and Medical Research Council of Australia ${ }^{7}$ have recommended the consumption of low Gl foods/diets to improve health. This recommendation is based on the establishment and diffusion of more appropriate methods for determining $\mathrm{Gl}^{2,3,8}$, including more accurate determination of available carbohydrate content ${ }^{9}$, and the existence of studies that consolidate the importance of consuming low Gl diets for preventing and treating diseases such as type 2 diabetes, cardiovascular diseases, obesity and some types of cancer ${ }^{10-13}$.

Despite the GI importance, the current barriers preventing the widespread use of this important education tool are the complexity of the associated concepts and the difficulties related to its use $\mathrm{e}^{5}$. Recently, emphasis has been placed on the need of publishing studies that provide instructions for its use, so scientific knowledge about the Gl can be disclosed in a way that ensures its clinical use ${ }^{5}$. Therefore, the purposes of the present study are to synthesize the main points regarding the use of the $\mathrm{Gl}$ and to provide information for its use in nutrition education in a way that encourages people to select foods that have a lower impact on blood glucose level.

METHODS

The electronic databases MedLine, ScienceDirect, SciELO and Lilacs were searched 
for studies published within the last 12 years that explored the importance of using the $\mathrm{Gl}$ and reported the main factors that influence the $\mathrm{Gl}$. Studies published before this period were included if newer scientific evidence were not available and/ or when their scientific relevance justified the inclusion. The main terms used for the search were: glycemic index, glycemic response, glycemic control, blood glucose, nutrition education, diabetes mellitus, chronic diseases.

This article contains the following sections: "Use of tables and sites for selecting foods according to their glycemic index"; "Factors that affect the glycemic index of foods"; "Use of the glycemic index in nutrition education"; and "Conclusions".

The glycemic index values indicated in this article are presented as mean \pm standard deviation, considering glucose as the reference food $^{14}$.

\section{RESULTS AND DISCUSSION}

\section{Use of tables and sites for selecting foods according to their glycemic index}

Knowing the impact that a food has on blood glucose level is an important step in nutrition education. Therefore, $\mathrm{Gl}$ tables and sites may be used to create foods lists according to Gl. These tables and sites were generated to avoid the unnecessary repetition of tests to determine the $\mathrm{Gl}$ of foods, to facilitate the use of $\mathrm{Gl}$ in studies and to inform the population about these values.

The most complete table currently available was created by Atkinson et al. ${ }^{14}$. It contains data from 205 studies published between 1981 and 2007. It also contains data from unpublished studies in which the obtained $\mathrm{Gl}$ values were based on the necessary methodological rigorousness. The Gl can also be accessed through the site <www. glycemicindex.com>, which was created by The
University of Sidney ${ }^{15}$, Australia. By clicking on "Gl data base" and writing the name of the food in English, it is possible to find the Gl of all foods that contain the written word in their name. The great advantage of using this site is that its data are constantly updated, so one can find the Gl of foods that have not yet been published.

Some considerations must be made about the use of these $\mathrm{Gl}$ tables and sites in nutrition education. GI may vary depending on the country in which the food was cultivated or produced. As an example, the $\mathrm{Gl}$ of bananas varies from $47 \pm 5$ for those grown in Australia to $70 \pm 5$ for the ones from South Africa. For this reason, whenever possible, to increase accuracy one should prefer to use the values obtained for foods from his/her home country, as long as the Gl has been determined in at least 10 non-diabetic individuals, as recommended by $\mathrm{FAO}^{2,16}$. Hence, international references should only be used when the domestic sources are not based on studies that used methodological rigorousness or when the $\mathrm{Gl}$ of the food in question is not found.

A glycemic index table was constructed in Brazil by researchers from the University of São Paulo ${ }^{17}$. This table contains the $\mathrm{Gl}$ of some of the most consumed preparations in the country according to the Family Budget Survey (Instituto Brasileiro de Geografia e Estatística) ${ }^{18}$. It can be found at <www.fcf.usp.br/tabela $>^{19}$. However, since this table is still under construction, the number of listed foods is still small.

The creation of $\mathrm{Gl}$ lists for nutrition education should be based on a previous selection of the carbohydrate source foods that are most consumed by the population of interest. Next, one should thoroughly search the Gl of these foods. Foods should then be listed according to food group and Gl classification. Thus, using glucose as the reference food, the Gl of foods or meals is classified as low $(\mathrm{Gl}<55)$, medium $(56<\mathrm{Gl}<69)$ or high $(\mathrm{Gl}>70)^{14}$. Chart 1 shows an example of such a list, which was created based on the most consumed Brazilian foods. 
Chart 1. Classification of foods according to their glycemic index.

\begin{tabular}{|c|c|c|}
\hline \multicolumn{3}{|c|}{ Classification of foods } \\
\hline Low glycemic index & Medium glycemic index & High glycemic index \\
\hline \multicolumn{3}{|c|}{ Breads, cookies, cakes and the like } \\
\hline $\begin{array}{l}\text { a Oat, bran } \\
\text { a Oat, flakes } \\
\text { b Banana cake } \\
\text { b Carrot cake } \\
\text { b Chocolate cake } \\
\text { a Cornstarch cookies } \\
\text { a Granola } \\
\text { a Whole light bread loaf }\end{array}$ & $\begin{array}{l}\text { b Cookie with wheat flakes } \\
\text { b Oat flake porridge } \\
\text { a Regular bread loaf }\end{array}$ & $\begin{array}{l}\text { ' Honey cookie } \\
\text { ' Cream cracker } \\
\text { b Iced cupcake } \\
\text { c Cornmeal cake } \\
\text { b Breakfast cereal made from corn } \\
\text { b Instant oat porridge } \\
\text { a Instant porridge (rice and oat) } \\
\text { ' Fruit cake with cinnamon } \\
\text { a French roll } \\
\text { ' French roll with chocolate } \\
\text { c Berliner doughnut (bakery) }\end{array}$ \\
\hline \multicolumn{3}{|l|}{ Milk, dairy products and the like } \\
\hline $\begin{array}{l}\text { b Whole milk } \\
\text { b Skim milk } \\
\text { b Soy milk } \\
\text { c Fermented milk } \\
\text { a Whole powdered milk } \\
\text { b Fruit yogurt }\end{array}$ & & ' Rice milk \\
\hline \multicolumn{3}{|l|}{ Fruits and juices } \\
\hline $\begin{array}{l}\text { a Mulberry } \\
\text { b Dried plum } \\
\text { a Banana (prata) and mysore } \\
\text { b Orange } \\
\text { a Fuji apple with peel } \\
\text { a Papaya } \\
\text { b Mango } \\
\text { a Strawberry } \\
\text { c Pear } \\
\text { b Apple juice }\end{array}$ & $\begin{array}{l}\text { a Pineapple } \\
\text { a Banana (nanica) } \\
\text { c Apricot } \\
\text { ' Orange juice without added sugar }\end{array}$ & b Watermelon \\
\hline \multicolumn{3}{|l|}{ Nuts and the like } \\
\hline \multicolumn{3}{|l|}{$\begin{array}{l}\text { ' Peanut } \\
\text { 'Cashew nut } \\
\text { a Cooked pine nuts }\end{array}$} \\
\hline \multicolumn{3}{|l|}{ Vegetables } \\
\hline $\begin{array}{l}\text { a Manioc, flour } \\
\text { b Cooked carrot } \\
\text { b Vegetable soup }\end{array}$ & $\begin{array}{l}{ }^{\mathbf{b}} \text { Cooked squash } \\
\text { b Cooked sweet potato } \\
{ }^{\text {a }} \text { Cooked arracacha }\end{array}$ & $\begin{array}{l}\text { a Cooked potato } \\
\text { b Cooked manioc } \\
\text { 'Yam }\end{array}$ \\
\hline $\begin{array}{l}\text { Grains and preparations } \\
\text { a White rice with beans } \\
\text { b Barley } \\
\text { b Pea } \\
\text { a Carioca beans } \\
\text { a Chickpea } \\
\text { b Soybean } \\
\text { b Lasagna } \\
\text { b Lentil } \\
\text { a Pasta (spaghetti) } \\
\text { b Whole pasta (spaghetti) } \\
\text { a Cooked pine nuts }\end{array}$ & a Cooked polenta (angu) & $\begin{array}{l}\text { a Cooked and seasoned white rice } \\
\text { b Wheat pancake } \\
\text { b Smashed potatoes } \\
\text { ' Mozzarella pizza } \\
\text { ' Cooked tapioca }\end{array}$ \\
\hline \multicolumn{3}{|l|}{ Sugars, beverages and desserts } \\
\hline $\begin{array}{l}\text { b Canned pineapple } \\
\text { b Chocolate } \\
\text { b Strawberry jam } \\
\text { b Canned peaches } \\
\text { b Sweet popcorn } \\
\text { b } \\
\text { b Ice cream }\end{array}$ & $\begin{array}{l}\text { 'C Condensed milk } \\
\text { b Honey } \\
\text { ' Marshmallow } \\
\text { 'Banana pie (without added sugar) } \\
\text { b Sucrose (table sugar) }\end{array}$ & $\begin{array}{l}\text { b Glucose } \\
\text { 'Iced doughnut } \\
\text { ' Energy drinks } \\
\text { c Jujube }\end{array}$ \\
\hline
\end{tabular}

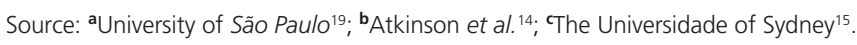




\section{Factors that affect the GI of foods}

The inclusion of high protein, fat or fiber foods in high-carbohydrate meals tends to reduce their impact on postprandial glycemia, reducing their Gl.

Proteins reduce postprandial blood glucose level by slowing gastric emptying and stimulating the secretion of incretins and of insulin ${ }^{20}$. On the other hand, fat tends to reduce blood glucose response because they reduce gastric emptying rate $^{21}$. The effect of soluble dietary fibers and, more recently, of insoluble dietary fibers, stems from the stimulation of incretin secretion, reduction of gastric emptying rate and reducing the availability of carbohydrates for absorption due to fiber-glucose binding 22 .

Given the above, the inclusion of high protein foods, such as milk and dairy products, lean meats, gelatin, egg whites and legumes, can be an interesting strategy for controlling the impact of carbohydrate foods on postprandial blood glucose level20,23,24. Similarly, the inclusion of high-fat foods, such as nuts and peanuts, in high-carbohydrate meals, and the of oils that are good source of polyunsaturated and monounsaturated fatty acids, such as olive oil, to high-Gl foods, such as potatoes $(\mathrm{Gl}=78 \pm 4$ ) or manioc $(G l=94 \pm 11)$, may be healthy alternatives for reducing their Gls. The consumption of high fiber foods, such as fruits, vegetables, legumes and some types of grains, such as oats, should also be encouraged, because of their ability to reduce postprandial blood glucose level25,26. The consumption of beans in association with white rice $(I G=73 \pm 4)$ or the inclusion of oat bran or legume flours in meals may also help to reduce postprandial blood glucose level because of their high fiber content.

Also, the ways in which foods containing carbohydrate are presented, processed and prepared may also influence their $\mathrm{Gl}$. The intake of solid foods tends to have a smaller impact on blood glucose level than fluid foods, so people should always prefer the former. Some examples are cooked potatoes $(\mathrm{Gl}=78 \pm 4)$ versus mashed potatoes $(\mathrm{Gl}=87)$, and orange $(\mathrm{Gl}=43 \pm 3)$ versus orange juice $(\mathrm{Gl}=50 \pm 2)$. Although the difference between the Gl of a solid and fluid food is small, the differences add up and may have an important effect on daily dietary GI.

The different ways of processing starch also affects postprandial blood glucose level. As the degree of processing or hydrolyzation increases, so does the access by digestive enzymes, increasing the rate of digestion and absorption ${ }^{27}$. Hence, one should always prefer unrefined products, such as whole rice or bread, cookies and cakes made with whole wheat flour. Instant foods or those high carbohydrate foods that can be prepared very quickly should be avoided.

Hydration causes starch gelatinization, which eases its digestion. This process depends on the amount of water used, the period of time in which the food is cooked, and temperature used. The use of high temperatures for prolonged periods associated with excess water destroys the granular structure of starch and increases its digestibility and impact on blood glucose level ${ }^{27}$. Thus, foods should be cut in bigger chunks for cooking, avoiding cooking excessively and using the minimal amount of water. Yams cooked without water resulted in lower blood glucose responses and Gls compared with those cooked in water ${ }^{28}$. Cookies have a high content of less digestible starches ${ }^{29}$.

On the other hand, lowering the temperature after the starch is hydrated leads to a phenomenon called retrogradation, which changes its conformation and makes it more resistant to digestion. Therefore, cooling foods reduces the amount of digestible starch. However, the time necessary for this change in conformation, the degree of resistance to digestion and reversibility of the process will depend on the type of structure presented by the starch $^{30}$.

Starch consists of two basic structures, amylopectin, with branched glucose chains joined by glycosidic bonds of the type $\alpha(1 \rightarrow 4)$ and $\alpha$ 
$(1 \rightarrow 6)$, and amylose, with linear chains joined by $\alpha(1 \rightarrow 4)$ bonds. While for amylose the formation of resistant starch is irreversible, for amylopectin resistant starch can be reverted in excess water and temperatures above $70^{\circ} \mathrm{C}^{30}$. For this reason, different foods may show distinct behaviors when heated. This has been demonstrated by a Brazilian study that reported a significant reduction in the $\mathrm{Gl}$ of legumes (beans and chickpeas) after cooling. However, the Gl of pasta and polenta (coarsely or finely ground yellow or white maize) did not change after cooking, freezing and reheating ${ }^{31}$.

The presence or addition of enzyme inhibitors, phytosterols, organic acids and resistant starch to foods/meals may help to reduce blood glucose response and their $\mathrm{Gl}$. The addition of $\alpha$-amylase inhibitors extracted from white beans reduced the $\mathrm{Gl}$ of white bread ${ }^{32}$. Isoflavones, a type of phytosterol found in soybeans, are capable of reducing postprandial blood glucose level by mechanisms that are not yet clear ${ }^{33}$. The addition of organic acids to meals, regardless of whether or not they were produced by fermentation (example: acetic acid from vinegar, citric acid from lime, lactic acid from yogurt) may also help to reduce blood glucose response ${ }^{34,35}$. Resistant starch, which does not increase blood glucose level, is present in flours such as green bananas flour. This type of flour can be used to replace other sources of available starch ${ }^{36}$. Knowing these factors, scientists and the food industry can work together to produce healthier foods, which have lower $\mathrm{Gl}$.

Caffeine on the other hand is responsible for increasing the blood glucose response after the doncumption of subsequent meals ${ }^{37}$. Therefore, the ingestion of high caffeine content beverages, such as coffee, teas and sodas, may increase the $\mathrm{Gl}$ of foods. For that reason, they should be avoided.

The cultivar, species and degree of maturation are also factors that may affect Gl. The Gl of bananas change according to these parameters. While one Brazilian type of banana (banana prata) has a Gl of 27, the mysore has a $\mathrm{Gl}$ of 49 and the common banana (nanica) has a
Gl of $61^{19}$. Furthermore, unripe fruits have a lower impact on blood glucose level than ripe fruits ${ }^{38}$. However, in general fruits have lower Gl.

\section{Use of the glycemic index in nutrition education}

The $\mathrm{Gl}$ should be considered as an additional tool for choosing dietary carbohydrate sources to be included as part of a nutritionally balanced diet, capable of promoting and/or maintaining appropriate body weight and health ${ }^{16}$. These carbohydrate sources can be important sources of vitamins, minerals and other components essential to health, such as phytochemicals and antioxidants ${ }^{3}$. Note that the intake of foods that are not very nutritious, such as soda $(\mathrm{Gl}=59 \pm 3)$, popcorn $(\mathrm{Gl}=65 \pm 5)$ and chocolate $(\mathrm{Gl}=40 \pm 3$ ), should be avoided, regardless of their medium (soda and popcorn) or low (chocolate) GI values. Hence, choosing foods to be part of a healthy diet cannot be based only on their $\mathrm{Gl}$.

As mentioned earlier, another important consideration is that the $\mathrm{Gl}$ can be affected by a number of factors. It is possible to use these factors for reducing the impact of high-Gl foods on postprandial blood glucose level. This information deserves to be emphasized because high-Gl foods can be included in the diet. However, these foods should be consumed in association with other foods of good nutritional quality that help to reduce postprandial blood glucose level. White rice is a food with high Gl consumed daily by most Brazilians. However, its consumption in associated with beans, helps to reduce postprandial blood glucose level since beans have a high content of fibers and protein.

Although the intake of foods/meals that cause a smaller increase in blood glucose level is often preferable (foods with low GI), in some situations, for example, hypoglycemia or for the maintenance/recovery of glycogen storages in athletes, the consumption of foods/meals that favor an increase in blood glucose levels may be indicated $^{16,21}$. 


\section{CONCLUSION}

Lists of the glycemic index should be created and used in nutrition education. These lists should be based on information taken from reliable tables and sites, and should contain the foods most commonly consumed by the population. People should be advised to select lower Gl foods and to prepare them in a way that will avoid high increases on their blood glucose levels. Whole foods should be preferently consumed instead of refined foods, purees and juices. Moreover, foods should not be overcooked, water should not be used in excess and high temperatures should be avoided. Cooked legumes should be frozen. High Gl foods should be consumed in association with those of good nutritional quality, such as lean protein and olive oil, which are capable of reducing the blood glucose level. The intake of high-caffeine foods should be made with caution to avoid steep rises in blood glucose level.

\section{COLLABORATORS}

FG CÂNDIDO helped to select and critically analyze scientific articles, participated in meetings to discuss the theme and development of the issue and structured and wrote the article. EV PEREIRA helped to select and critically analyze scientific articles, participated in meetings to discuss the theme, created a reference table containing the glycemic index of foods and reviewed the article. RCG ALFENAS helped to select and critically analyze scientific articles, participated in meetings to discuss the theme and development of the issue, and structured, wrote and reviewed the article.

\section{REFERENCES}

1. Jenkins DJ, Wolever TM, Taylor RH, Barker $H$, Fielden $\mathrm{H}$, Baldwin JM, et al. Glycemic index of foods: a physiological basis for carbohydrate exchange. Am J Clin Nutr. 1981; 34(3):362-6.

2. Brouns F, Bjorck I, Frayn KN, Gibbs AL, Lang V, Slama $G$, et al. Glycaemic index methodology. Nutr Res Rev. 2005; 18(1):145-71. doi: S0954422405000 119[pii]10.1079/NRR2005100.
3. Food and Agriculture Organization. Carbohydrates in human nutrition: report of a joint food and agriculture report. In: Food and Nutrition Paper. Rome: FAO; 1998 [cited 2011 Oct 10]. Available from: <http://www.fao.org/docrep/w8079e/ w8079e00.htm>.

4. Wolever TM, Jenkins DJ. The use of the glycemic index in predicting the blood glucose response to mixed meals. Am J Clin Nutr. 1986; 43(1):167-72.

5. Grant SM, Wolever TM. Perceived barriers to application of glycaemic index: valid concerns or lost in translation? Nutrients. 2011; 3(3):330-40. doi: 10.3390/nu3030330nutrients-03-00330 [pii].

6. European Association for the Study of Diabetes Recommendations for the nutritional management of patients with diabetes Mellitus. Eur J Clin Nutr. 2000; 54:353-5.

7. National Health and Medical Research Council. Dietary guidelines for older Australians. Canberra: AusInfo; 1999.

8. Foster-Powell K, Holt SH, Brand-Miller JC. International table of glycemic index and glycemic load values: 2002. Am J Clin Nutr. 2002; 76(1): 5-56.

9. McCleary BV, Monaghan DA. Measurement of resistant starch. J AOAC Int. 2002; 85(3):665-75.

10. Ludwig DS. Dietary glycemic index and obesity. J Nutr. 2000; 130(2):280-3.

11. Schulze MB, Liu S, Rimm EB, Manson JE, Willett WC, Hu FB. Glycemic index, glycemic load, and dietary fiber intake and incidence of type 2 diabetes in younger and middle-aged women. Am J Clin Nutr. 2004; 80(2):348-56. doi: 10.1016/j.jfca.200 7.02.004.

12. Amano Y, Kawakubo K, Lee JS, Tang AC, Sugiyama M, Mori K. Correlation between dietary glycemic index and cardiovascular disease risk factors among Japanese women. Eur J Clin Nutr. 2004; 58(11): 1472-8. doi: 10.1038/sj.ejcn.16019921601992 [pii].

13. Augustin LS, Dal Maso L, La Vecchia C, Parpinel M, Negri E, Vaccarella $S$, et al. Dietary glycemic index and glycemic load, and breast cancer risk: a casecontrol study. Ann Oncol. 2001; 12(11):1533-8.

14. Atkinson FS, Foster-Powell K, Brand-Miller JC. International tables of glycemic index and glycemic load values: 2008. Diabetes Care. 2008; 31(12): 2281-3. doi: dc08-1239 [pii]10.2337/dc08-1239.

15. The University of Sidney. Home of the glycemic index. Sidney: The University of Sidney; 2011 [cited 2011 Oct 9]. Available from: <http://www. glycemicindex.com/>.

16. Arvidsson-Lenner R, Asp N-G, Axelsen M, Bryngelsson S, Haapa E, Järvi A, et al. Glycaemic Index. 
Relevance for health, dietary recommendations and food labelling 2004. Food Nutr Res. 2004; 48(2):1-8.

17. Menezes EW, Giuntini EB, Dan MCT, Lajolo FM. New information on carbohydrates in the Brazilian food composition database. J Food Compos Anal. 2009; 22(5):446-52. doi:10.1016/j.jfca.2009. 02.001 .

18. Instituto Brasileiro de Geografia e Estatística. Pesquisa de Orçamentos Familiares 2002-2003. Análise da disponibilidade domiciliar de alimentos e do estado nutricional no Brasil. Rio de Janeiro: IBGE; 2004.

19. Universidade de São Paulo. Tabela brasileira de composição de alimentos. São Paulo: USP; 2008 [acesso 2011 out 10]. Disponível em: <http://www. fcf.usp.br/tabela/>.

20. Karamanlis A, Chaikomin R, Doran S, Bellon M, Bartholomeusz FD, Wishart JM, et al. Effects of protein on glycemic and incretin responses and gastric emptying after oral glucose in healthy subjects. Am J Clin Nutr. 2007; 86(5):1364-8. doi: 86/5/1364 [pii].

21. Gentilcore D, Chaikomin R, Jones KL, Russo A, Feinle-Bisset C, Wishart JM, et al. Effects of fat on gastric emptying of and the glycemic,insulin, and incretin responses to a carbohydrate mealin type 2 diabetes. J Clin Endocrinol Metab. 2006; 91(6): 2062-7. doi: jc.2005-2644 [pii]10.1210/jc.2005-2644.

22. Ou S, Kwok K, Li Y, Fu L. In vitro study of possible role of dietary fiber in lowering postprandial serum glucose. J Agric Food Chem. 2001; 49(2):1026-9. doi: jf000574n [pii]

23. Ostman EM, Liljeberg Elmstahl HG, Bjorck IM. Inconsistency between glycemic and insulinemic responses to regular and fermented milk products. Am J Clin Nutr. 2001; 74(1):96-100.

24. Chung H-J, Liu Q, Hoover R, Warkentin TD, Vandenberg B. In vitro starch digestibility, expected glycemic index, and thermal and pasting properties of flours from pea, lentil and chickpea cultivars. Food Chem. 2008; 111(2):316-21. doi: 10.1016/j. foodres.2008.03.013.

25. Giacco R, Parillo M, Rivellese AA, Lasorella G, Giacco A, D'Episcopo L, et al. Long-term dietary treatment with increased amounts of fiber-rich low-glycemic index natural foods improves blood glucose control and reduces the number of hypoglycemic events in type 1 diabetic patients. Diabetes Care. 2000; 23(10):1461-6. doi: 10.2337/ diacare.23.10.1461

26. Mira GS, Graf H, Cândido LMB. Visão retrospectiva em fibras alimentares com ênfase em beta-glucanas no tratamento do diabetes. Braz J Pharm Sci. 2009; 45(1):11-20.

27. Lehmann U, Robin F. Slowly digestible starch - its structure and health implications: a review. Trends
Food Sci Tech. 2007; 18(7):346-55. doi: 10.1016/ j.tifs.2007.02.009.

28. Kouassi NK, Tiahou, GG, Abodo, JRF, Camara-Cisse, $\mathrm{M}$, Amani, GN. Influence of the variety and cooking method on glycemic index of Yam. Pakistan J Nutr. 2009; 8(7):993-9.

29. Englyst KN, Vinoy S, Englyst HN, Lang V. Glycaemic index of cereal products explained by their content of rapidly and slowly available glucose. $\mathrm{Br} J$ Nutr. 2003; 89(3):329-40. doi: 10.1079/BJN2002786 S0007114503000400 [pii].

30. Walter M, Silva LP, Emanuelli T. Amido resistente: características físico-químicas, propriedades fisiológicas e metodologias de quantificação. Ciênc Rural. 2005; 35:974-80.

31. Carreira MC, Menezes EW. Índice glicêmico de alimentos brasileiros: efeito do armazenamento sob baixa temperatura $\left(-20^{\circ} \mathrm{C}\right)$. São Paulo; 2001.

32. Udani JK, Singh BB, Barrett ML, Preuss HG. Lowering the glycemic index of white bread using a white bean extract. Nutr J. 2009; 8:52. doi: 1475-2891-8-52 [pii]10.1186/1475-2891-8-52.

33. Kwon DY, Daily JW, Kim HJ, Park S. Antidiabetic effects of fermented soybean products on type 2 diabetes. Nutr Res. 2010; 30(1):1-13. doi: S02715317(09)00245-0 [pii]10.1016/j.nutres.2009. 11.004.

34. Johnston CS, Buller AJ. Vinegar and peanut products as complementary foods to reduce postprandial glycemia. J Am Diet Assoc. 2005; 105(12):1939-42. doi: S0002-8223(05)01222-8 [pii]10.1016/j.jada.2005.07.012.

35. Schakel S, Schauer R, Himes J, Harnack L, Van Heel $\mathrm{N}$. Development of a glycemic index database for dietary assessment. J Food Comp Anal. 2008; 21(0):50-5. doi: 10.1016/j.jfca.2007.02.004.

36. Aparicio-Saguilán A, Sáyago-Ayerdi SG, VargasTorres A, Tovar J, Ascencio-Otero TE, Bello-Pérez LA. Slowly digestible cookies prepared from resistant starch-rich lintnerized banana starch. J Food Comp Anal. 2007; 20(3-4):175-81. doi: 10.1016/j.jfca.2006.07.005.

37. Moisey LL, Kacker S, Bickerton AC, Robinson LE, Graham TE. Caffeinated coffee consumption impairs blood glucose homeostasis in response to high and low glycemic index meals in healthy men. Am J Clin Nutr. 2008; 87(5):1254-61. doi: 87/5/ 1254 [pii].

38. Brennan CS. Dietary fibre, glycaemic response, and diabetes. Mol Nutr Food Res. 2005; 49(6):560-70. doi: $10.1002 / \mathrm{mnfr} .200500025$. 